Research Paper

\title{
Investigating the Relationship Between Mindfulness and Social Support and Mental Health of Mothers with Mentally Retarded Child
}

\author{
Yadollah Ghasemipour ${ }^{* 1}$, Behnaz Roshan ${ }^{2}$
}

1. Assistant Professor, Department of Psychology, Faculty of Literature and Humanities, Malayer University, Hamedan, Iran 2. M.A. in General Psychology, Faculty of Literature and Humanities, Malayer University, Hamedan, Iran

Accepted: March 8, 2019

\begin{abstract}
Abstact
Background and Purpose: The existence of a mentally retarded child in a family compromises the mental health of the members, however, other variables play a role in explaining the psychological status of the parents of these children. The purpose of this study was to investigate the relationship between mental health and social support and mindfulness of mothers with a mentally retarded child.

Method: A total of 92 mothers with at least one mentally retarded child aged 6 to 14 were selected as the sample. The data were collected through mindful attention awareness scale (Brown and Ryan, 2003), multidimentional scale of percieved social support (Zimet, Dahlem, Zimet, \& Farley,1998), and depression, anxiety and stress scale (Lovibond \& Lovibond, 1995). Data were analyzed using Pearson correlation test and multivariate regression.

Results: The results showed that there was a significant negative relationship between the depression, anxiety and stress scores $(\mathrm{p}<0.01)$. But there was no significant relationship between mothers' mental health and social support. The results also showed that the mindfulness could significantly predict depression $(\beta=0.50)$ and anxiety $(\beta=0.46)$ of mothers $(P<0.001)$, but maternal stress was not predicted by any of the variables of mindfulness and social support.

Conclusion: The significant relationships between mindfulness and mental health of mothers with mentally retarded children highlights the necessity of psychological interventions based on mindfulness.
\end{abstract}

Keywords: Minfulness, social support, mental health, mental retardation

Citation: Ghasemipour Y, Roshan B. Investigating the relationship between mindfulness and social support with mental health of mothers with mentally retarded child. Quarterly Journal of Child Mental Health. 2019; 6(1): 176-187.

\footnotetext{
*Corresponding author: Yadollah Ghasemipour, Assistant Professor, Department of Psychology, Faculty of Literature and Humanities, Malayer University, Hamedan, Iran.

Email: Y.ghasemipour@malayeru.ac.ir

Tel: (+98) 81-32355348
} 


\title{
نقش ذهن آكاهى و حمايت اجتماعى در يیشبينى سلامت روان مادران داراى كودك كم توان ذهنى
}

\author{
يداله قاسمى يور"'، بهناز روشن' \\ ا. استاديار كروه روانشناسى، دانشكده ادبيات و علوم انسانى، دانشكاه ملاير، همدان، ايران

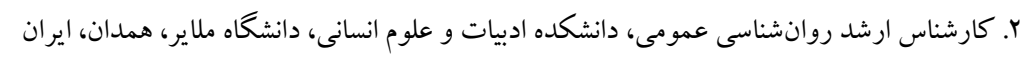

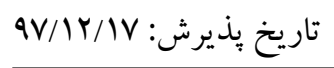

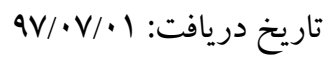

\section{جكيده}

زمينه و هدف: وجود كودكى كم توان ذهنى در يكك خانواده، سـلامت روانى اعضـاى آن را به خطر مىاندازد، با اين وجود متغيرهاى

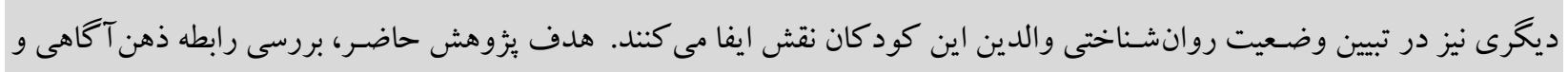
حمايت اجتماعى با سلامت روانى مادران داراى كود كى كم توان ذهنى بود.

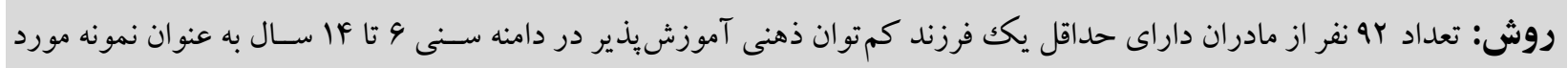

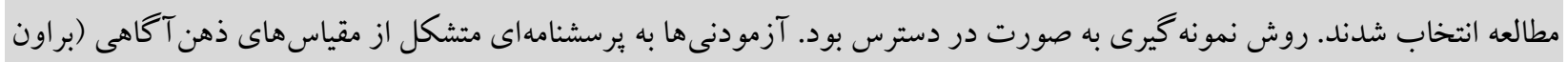

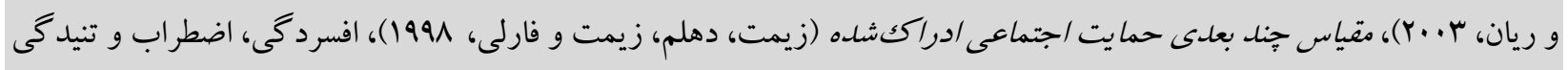

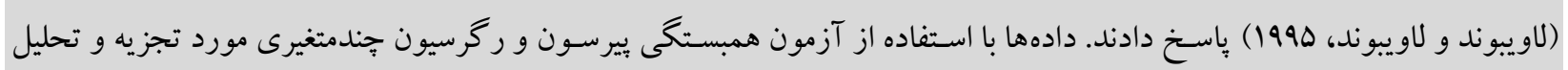
قرار گرفت.

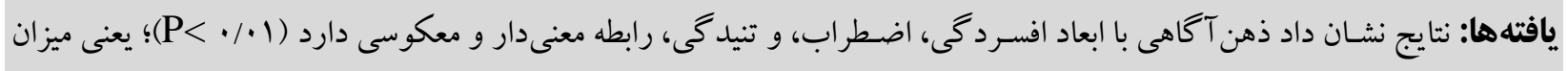

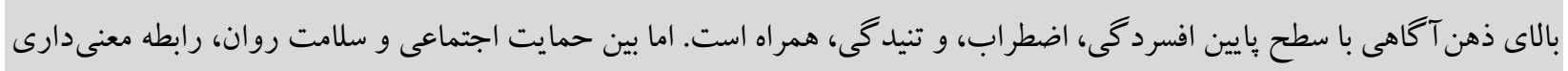

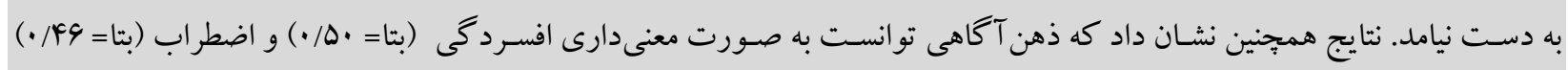

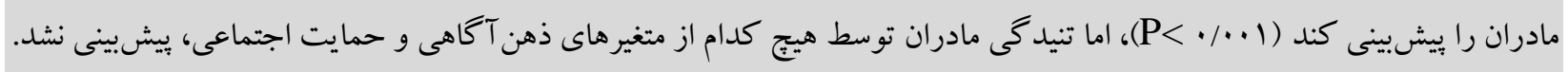

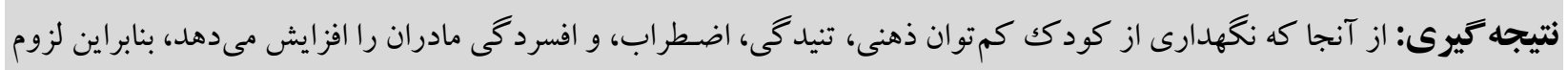

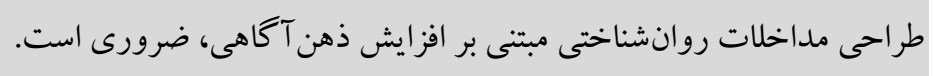
كليدوازهها: ذهن آكاهى، حمايت اجتماعى، سلامت روان، كم توانى ذهنى

*نويسنده مسئول: يداله قاسمىيور، استاديار كروه روانشناسى، دانشكده ادبيات و علوم انسانى، دانشكاه ملاير، همدان، ايران. تلفن: Al-rrTADHFA

ايميل:M.ghasemipour@malayeru.ac.ir 
كود كان اثر كذار باشد، ذهن آكاهى' است ( •او 1|). از سوى ديخر يزوهشهاى متعددى اين نكته را تأييد كردهاند كه هر ته آنه ميزان حمايت اجتماعى افزايش يابد، سـطح سلامتى نيز افزايش

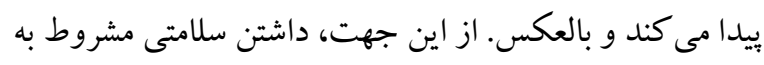

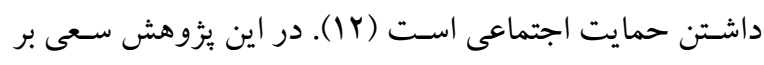

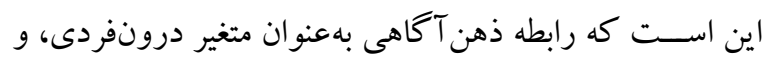

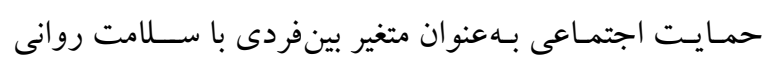

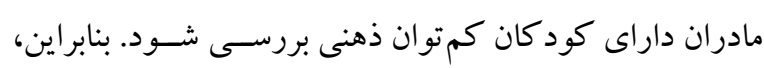

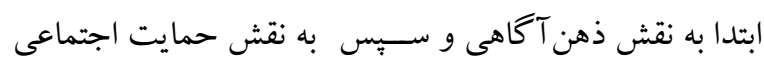
يرداخته مى شود.

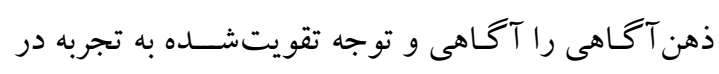

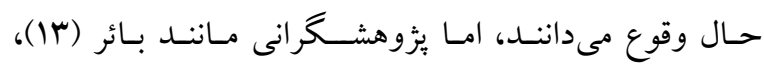
ويز گى هاى ديخرى مثل توجه غيرقضساو تى، بذيرند

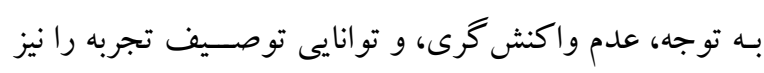

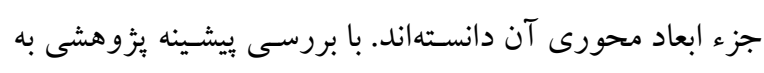

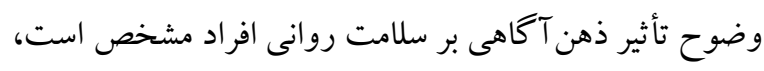

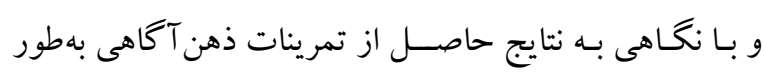

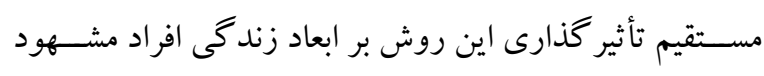

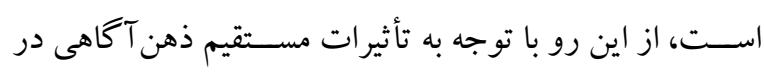

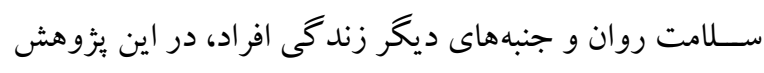
ذهن آكاهى را بهعنوان يكى از متغيرهايى كه تا حدى مى دوتواند

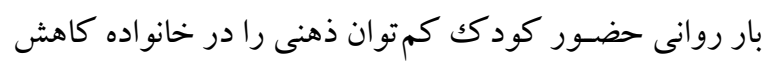
دهد، مورد بررسى قرار مىدهيم. در اين رابطه، نتايج مطالعات

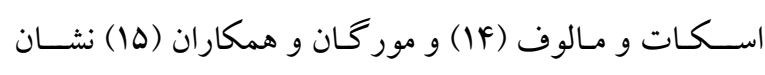

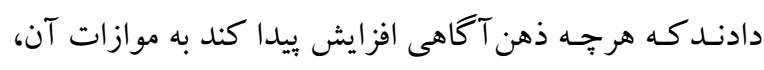

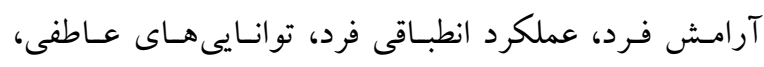

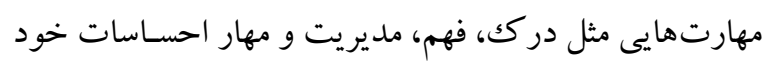

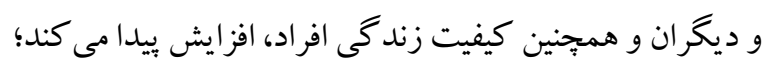

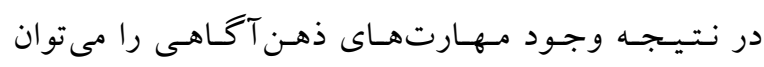
تضمين كننده سلامت روانى فرد دانست.
مقله يكى از طبيعى ترين نيـازهـاى انســان، تعلق به خانو اده اســت.

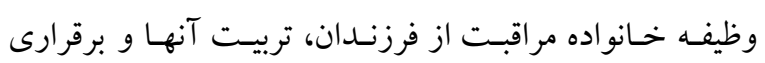

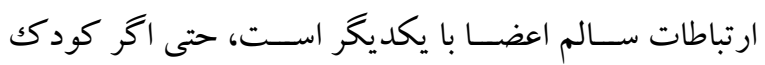

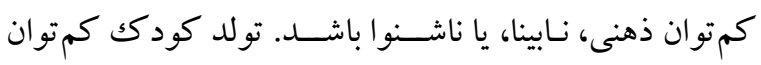
ذهنى اغلب به عنوان شـوك شديدى در خانو اده تلقى مى شود

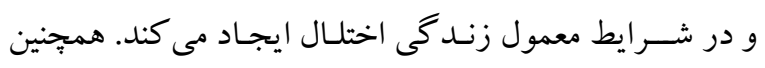
والـدين كود كـان كم توان ذهنى حسالـات هيجـانى نـإيـايـدار،

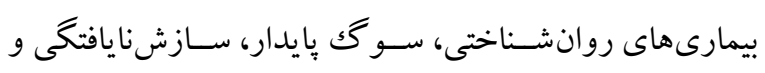
انزواى اجتمـاعى، و همجنين دردهـاى فيزيكى مانند كمردرد،

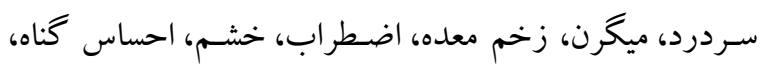

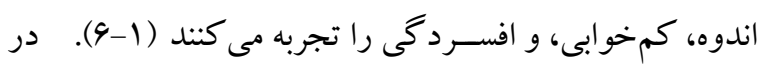

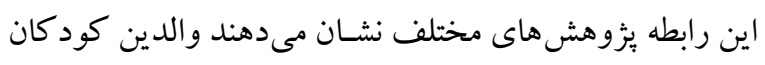
كمتوان ذهنى، ســلـامت جســمانى و روانى بايين ترى دارند.

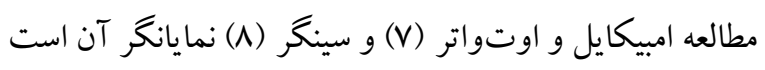

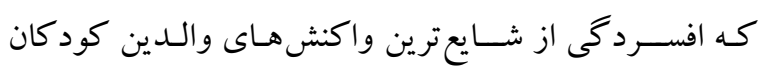

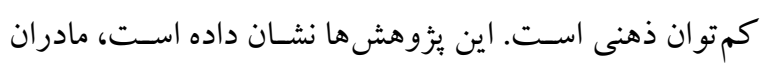

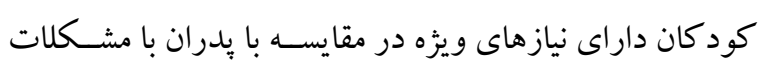

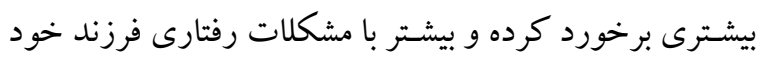

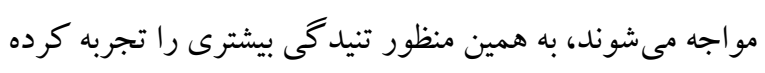

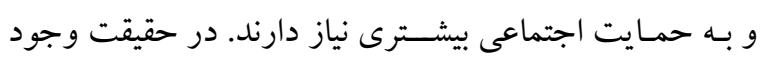

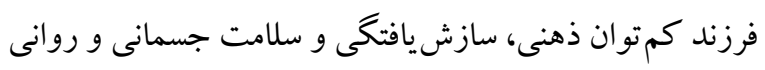

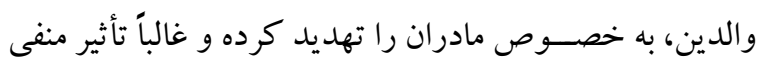
بر رضـايتمندى آنها دارد (9). وجود كود كك كم تو ان ذهنى در خانو اده اغلب ضايعات جبراننايذيرى بر ييكر خانو اده وارد

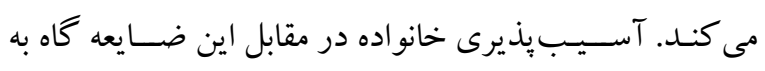
حدى اسـت كه وضعيت سـلامت روانى خانو اده دجار آسـيب شديدى مىشود. متغيرهايى جهت كاستن يا تعديل عوارض حضور كود كود

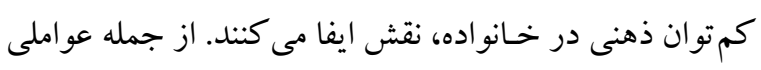
كه مى تواند در كاهش آشفتكى هاى روانى ناشى از داشتن اين

1. Mindfulness 
حمـايت گر به همر اه ويز گى هاى شــخصــــى فرد مانند ميزان ذهن آكاهى، تأثير مسـتقيمى بر كيفت و سـلامت روانى والدين

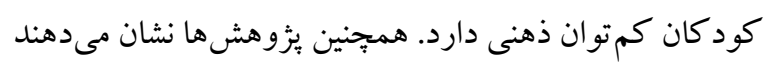

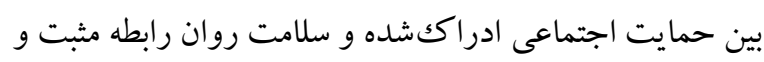
معنى دارى وجود دارد (9 ، • (YF-Y) دربـاره تعريف حمـايست اجتمـاعى نظرات متفـاوتى مورد دارد توجه اسـت. اين اصـطلاح گاهى به وجود روابط اجتماعى يا

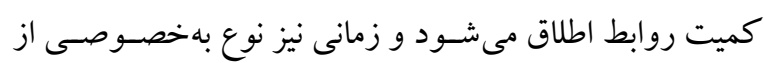

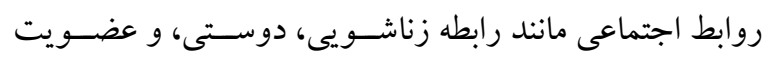

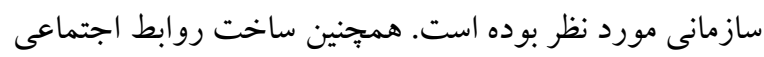
و محتواى كاركردى روابط نيز از جمله مواردى هستند كه در مر ماردئ

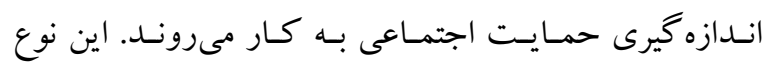

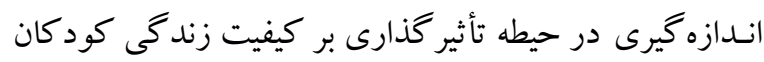
مبتلا به كم توان ذهنى به كار رفته است (YD)

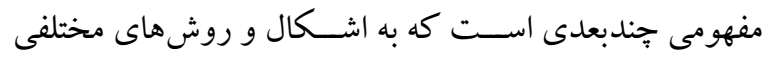

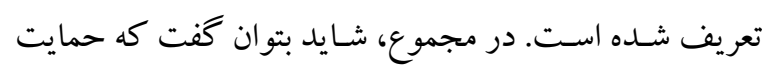
اجتماعى يعنى اين احسـاس كه شــص مورد توجه ديخران

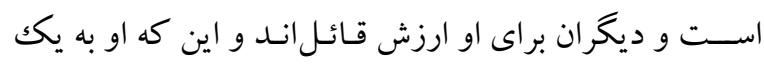
شبكه اجتماعى متعلق است (Y) (I).

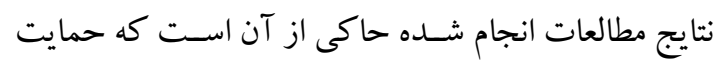

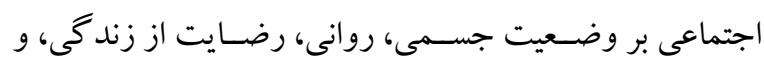

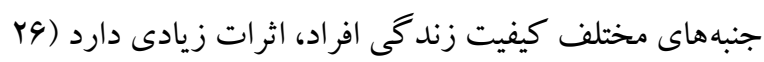

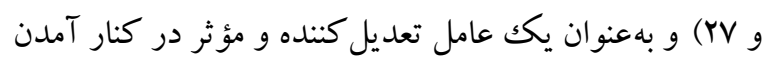

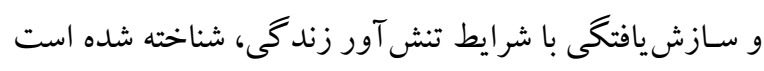

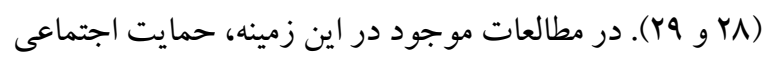

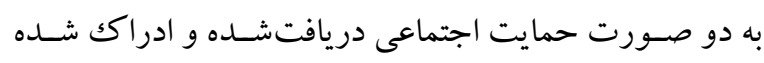

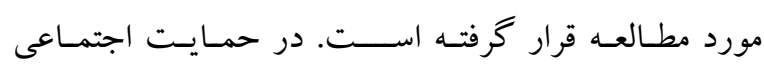
دريافتشـده، ميزان حمايتهاى كسـبـشه توسط فرد، مورد

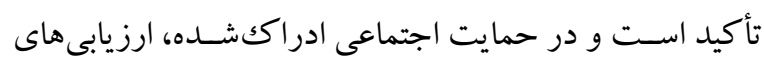
فرد از در دسـترس بودن حمايت ها درمواقع ضــرورى و مورد

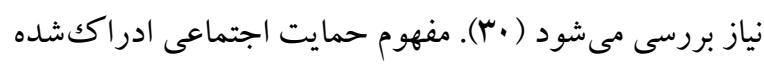

2. Enhanced
در واقع، ذهن آكاهى شـكلى از مراقبه اسـت كه ريشـه در

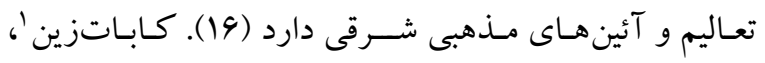

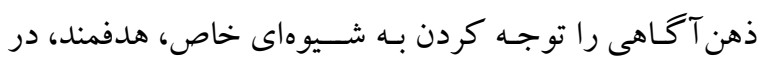
زمان كنونى و بدون قضاوت و ييشداورى تعريف كرده است بت بـ

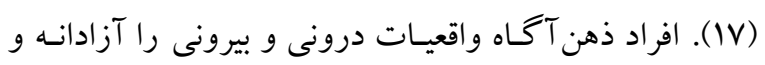

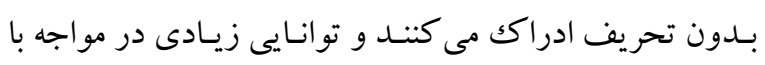

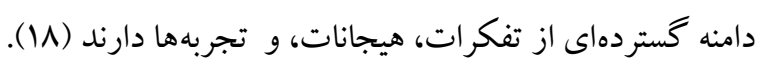

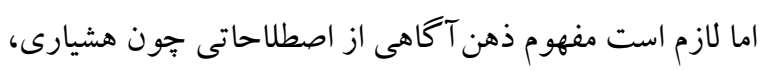

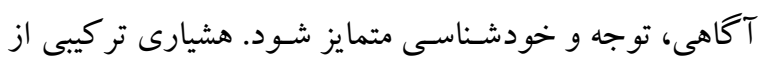
توجه و آكاهى اسـت. آكاهى مانند زمينه يا صففحه رادار گونه هشيارى عمل مى كند كه در اين صفحهه يا زمينه، محر ككهاى

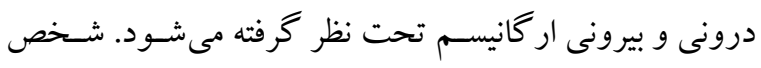

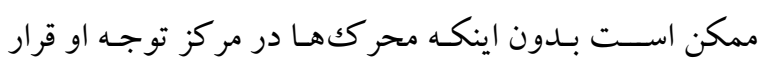
كيرند از آنها آكاه باشد. توجه، آكاهى هشيارانه متمر كز است و حسـاسـيت به دامنه محدودى از تجارب را شـامل مىشـود.

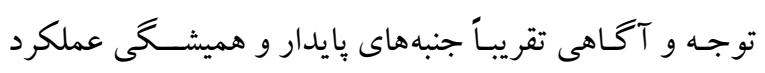

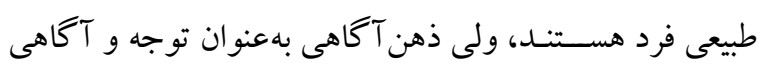

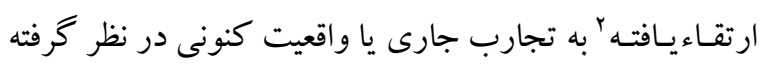
مىشود (19). (19)

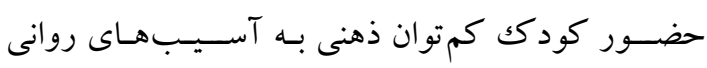
مشـخص ديخرى از جمله اضـطراب و افسـرد كَى در والدين

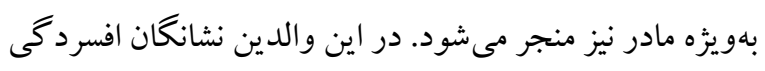
و از هم گسيختكى خانوادگى بيشترى ديده مى شود و همبحنين فرصت كمترى براى خود و سلامت جسمى و روانى خود قائل

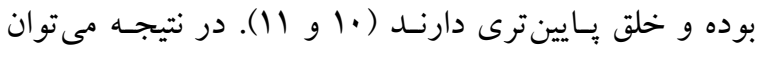
سلامت روانى والدين را تابعى از حضور كودك كم توان ذهنى

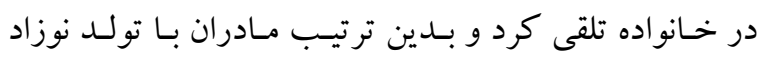

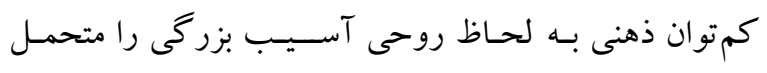

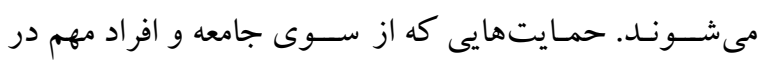
زندكى اين مادران وجود دارد متضـمن سلامتى روان اين افراد است. در اين رابطه نتايج مطالعات حاكى از آن است كه جامعه 
تحصسيل بود و ملاكك خروج از يزوهش شـامل بىسـواد بودن

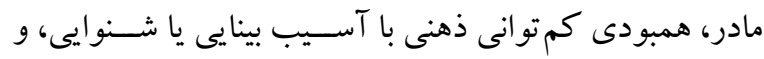
شدت كم توانى ذهنى متوسط، شديد، يا عميق بود.

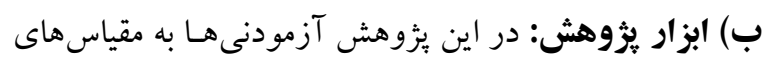

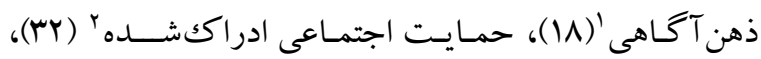

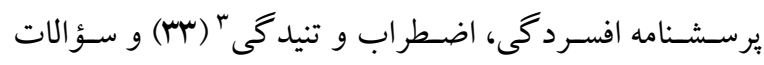
جمعيتشناختى ياسخ دادند.

ا. مقياس ذهن Tكاهى: اين مقياس توسـط بر براون و ريان (IN)

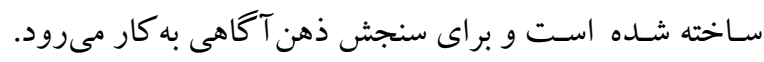
اين مقياس از اعتبار خ خوبى برخوردار است، بهطورى كه روى

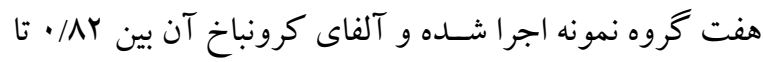

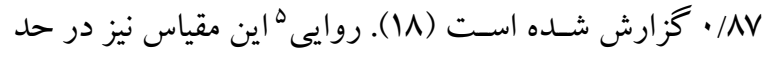

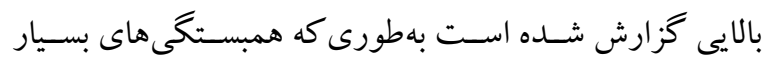

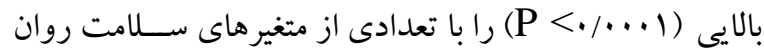
دارد (1)). همجنين روايى سازه و ملاكك اين مقياس در بيماران

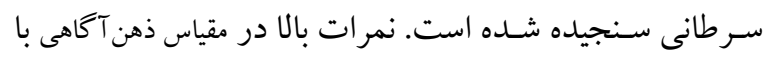

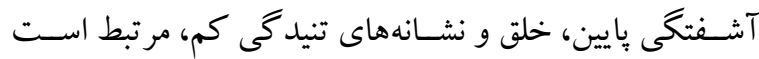

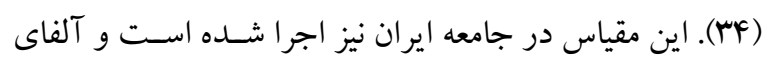

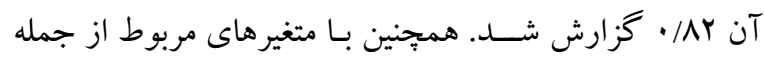

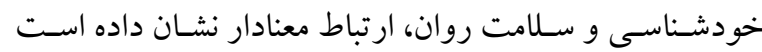

r. مقياس جندبعلى حمايت /جتماعى /دراكتشـده: اين مقياس

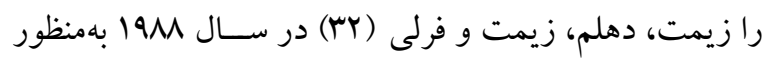
ســنش حمـايـت اجتمـاعى ادراككشــــه از طرف خانواده،

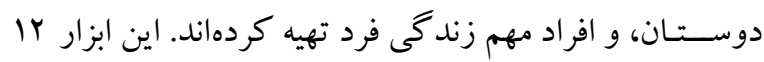

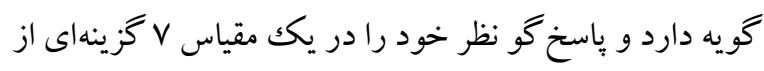

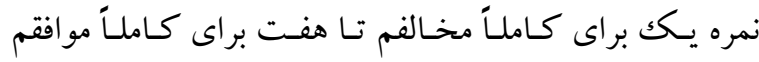

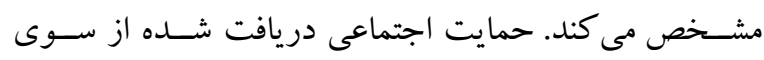

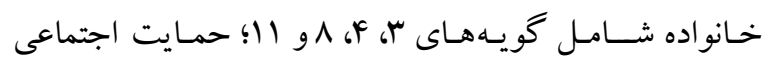
دريافت شده از سوى دوستان شامل گويههاى 9، V، 9 و و Iا؛ و

3. Depression, Anxiety and Stress Scale (DASS)

4. Reliability

5. Validity
به حمايت از ديد گاه ارزيابى شــناختى فرد از روابطش اشــاره دارد. نظريـه يردازان اين حوزه بر اين بـاورنـــ تمام روابطى كه

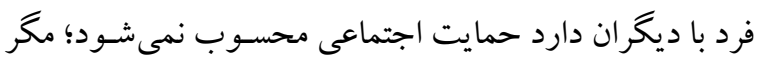

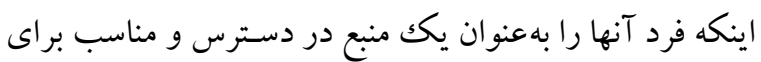

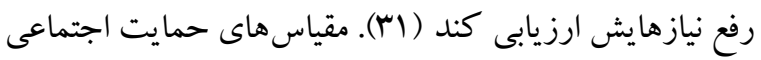

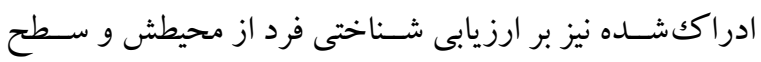

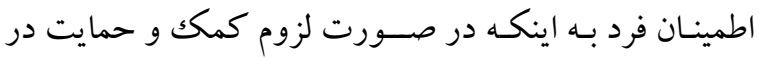
دسترس خواهد بود متمركز هستند (·r).

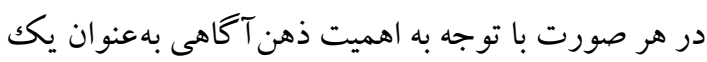

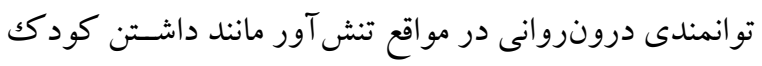

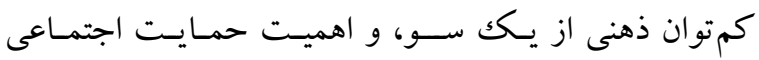

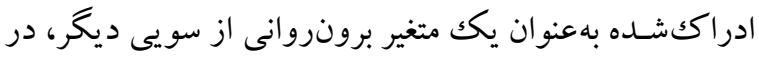

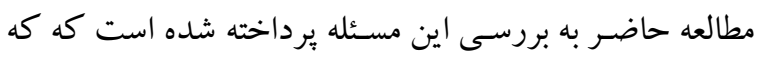

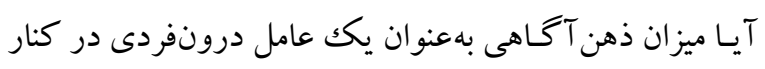
عـامـل برونفردى حمـايت اجتماعى با ســلامت روانى مادران داراى كود كك كم توان ذهنى رابطه معنادارى دارد يا خير؟. الف) جـامعه آمارى و نمونه يخووهش: جـامعه آمارى در اين

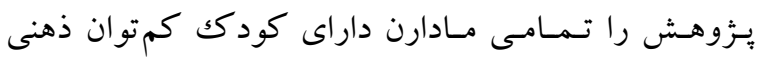

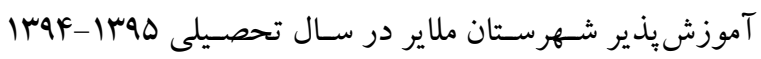
تشـكيـل دادنــ. اين كودكـان در مراكز آموزشــى كودكان

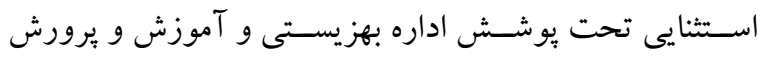
مشـغول به تحصـيل بودند و در دامنه سـنى 9 تأ fاسـال قرار داشتند. نمونه مورد مطالعه شــامل ra نفر از مادران داراى كودك

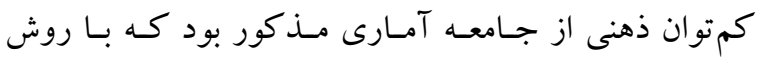
نمونه گيرى در دسترس از جامعه آمارى انتخاب شدند. ملاكى ورود به يثزوهش شـامل مادر تنى بودن و داشـتن حداقل يكك

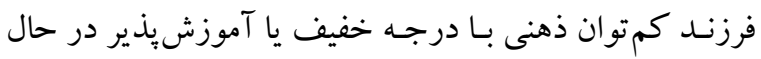

1. Mindful Attention Awareness Scale (MAAS) 2. Multidimentional Scale of Percieved Social Support (MSPSS) 
مـانـدن اطلـاعـات، در نظـر نـحرفتـن اطـلـاعـات هويتى شـركت كنند كان، و همجِنين رضـايت آنان در شر كت در اين

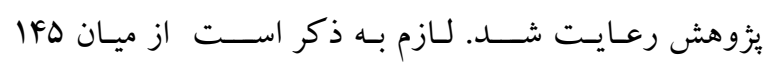
يرسـشنامهاى كه تكميل شد موارد نامعتبر آن كنار كذاشته شد و تعداد بوه يرسشنامه مورد تجزيه و تحليل نهايى قرار كرفت. جهت تجزيه و تحليل دادهها از روشهاى آمار توصـيفى (فراوانى، درصـد، ميانكين، انحراف اسـتاندارد) و براى آزمون فرضيه ها از روش آمارى همبستخى با نرمافزار SPSS نسخه بr

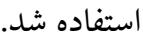

\section{يافتهها}

كروه مورد يثزوهش شـامل مادران دار اى حداقل يك كودكى

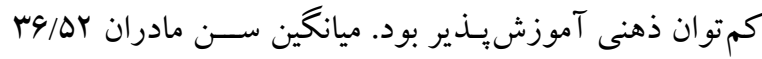

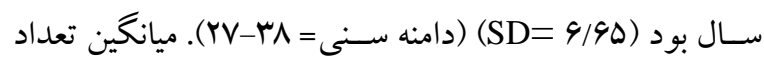
كـل فرزنـدان آنهـا نيز اب/Y فرزنـد بود. ســاير شــاخصهاى توصيفى مربوط به نمونه در جدول ا گزارش شده است.

جدول ا: وضعيت تأهل، تعداد فرزندان، اشتغال، جنسيت فرزند

\begin{tabular}{|c|c|c|c|}
\hline درصد & \multicolumn{2}{|c|}{ كمتوان ذهنى و ميزان تحصيلات آزمودنىها } & كم توان ذهن \\
\hline $9 \cdot / 9$ & $v \cdot$ & متأهل & \\
\hline$r / 9$ & r & 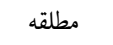 & تأهل \\
\hline$\Delta / r$ & r & بيوه & \\
\hline 11 & ro & 1 & \\
\hline r. & $F \mid / V$ & r & \\
\hline M & ro & $r$ & \\
\hline r & $\Delta / 9$ & r & تعداد فرزندان \\
\hline 1 & $1 / 4$ & $\Delta$ & \\
\hline 1 & $1 / 4$ & 4 & \\
\hline vr & $9 \pi$ & 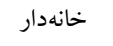 & \\
\hline $1 F / 9$ & 11 & 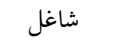 & \\
\hline$\Delta \mathrm{V} / \mathrm{I}$ & f. & دختر & جنسيت فرزند كمتوان \\
\hline$F Y / q$ & $r \cdot$ & يسر & \\
\hline $\mathrm{rq} / \mathrm{v}$ & rq & راهنمايى سوم & \\
\hline$F r / \Delta$ & m & دييلم & تحصيلات \\
\hline$r / V$ & r & فوق دييلم & \\
\hline $10 / 1$ & 11 & 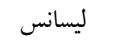 & \\
\hline
\end{tabular}

حمـايت اجتماعى دريافت شـــده از ســوى ديخران شــامل كويههاى ا، Y، هاو r ا است. در يكك مطالعه اعتبار درونى اين ابزار در يكك نمونه VM نفرى از جوانان دبيرسـتان با استفاده از آلفاى كرونباخ، \$1// • تا • 9/ • براى خردهمقياسهاى اين ابزار،

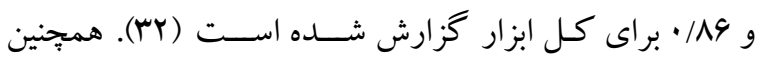
مر ادى، دهقانىزاده و ســليمانى خشـاب (هr) ضـرايب آلفاى كرونبـاخ عـامـل كلى حمـايست اجتماعى ادراككشــــه و ابعاد

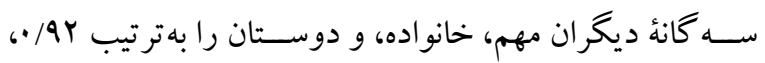

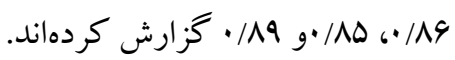
م. مقياس افسـردكى، اضطراب و تنيدكى: اين مقياس توسـط لاويبوند و لاويبوند (سM) در دو فرم كوتاه (اب كويهاى) و بلند

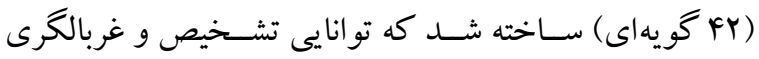
نشـانههاى افسردگى، اضطر اب، و تنيدگى را در طى يك هفته

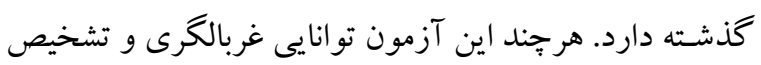
در دوره نوجوانى را نيز دارد، ولى بهتر است براى افراد بالاتر از ها سـال مورد اسـتفاده قرار گيرد. يايايى اين مقياس در جوامع غربى با آلفاى كرونباخ بالاى •9/ • به تأييد رسـيده اسـت. اين مقيـاس در جـامعه ايرانى نيز از يايايى خوبى برخوردار اســت

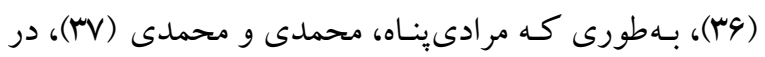
مطالعهاى بر روى بيماران قلبى، ضـرابى آلفاى كرونباخ 9F/•،

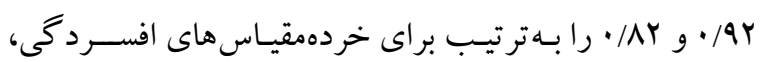

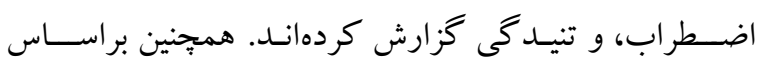
مطـالعـات كرافورد و هنرى (^^)، اين مقياس از روايى سـازه خوبى نيز برخوردار است. ج) روش اجرا: بعـد از انجـام مكـاتبـات با دانشــاه و اداره بهزيستى و آموزش و يرورش شهر ملاير و كسـب مجوزهاى للازم به مدارس اسـتثنايى مراجعه شــــ و با هماهنكى مديريت مدارس، ئزوهشـر در جلسـه اولياء و مربيان مدارس شـركت كرد و همكارى مادران را براى تكميل كردن برسـشــامههاى يثزوهش جلـب كردنـد. همجينين بثزوهشــر در محل يثزوهش حضـور داشـته و به برسـش هاى احتمالى آزمودنىها (مادران) ״ياســخ مى داد. ملاحظات اخلاقى در اين بئوهش مانند محرمانه 
بود. از اين ميان بو نفر يعنى حدود VY درصـد مادران خانهدار

بودند و حدود Ar درصسـد آنها مدركك تحصسيلى ديڤلم و زير

ديبلم داشتند. ميانخين و انحر اف استاندارد متغيرهاى يزخوهش و همبستگى بين آنها در جدول Y گز ارش شده شده است.
همانطور كه در جدول ا نشـان داده شـده اسـت •V نفر از

مادران متأهل بودند كه حدود ا9 درصد افراد مورد بزوهش را

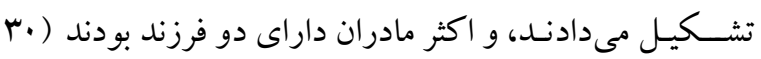

درصد) كه حداقل يكك نفر از فرزندان، مبتلا به كمتوانى ذهنى

\begin{tabular}{|c|c|c|c|c|c|c|c|c|c|c|c|c|}
\hline$\Lambda$ & $r$ & 7 & 0 & $\varepsilon$ & $r$ & $r$ & 1 & كشيدكى & جولكى & انحر اف معيار & ميانكين & متغير \\
\hline & & & & & & & 1 & $-\cdot / F F$ & $\cdot / 49$ & $10 / 90$ & $\$ 9 / \cdot 1$ & ا. ذهن آكاهى \\
\hline & & & & & & 1 & .119 & $\cdot / v$ & $-\cdot / \Delta \Lambda$ & $r /$ IV & $14 / 19$ & r. حمايت خانو اده \\
\hline & & & & & 1 & . $/$ \&r* & $-\cdot / \kappa$ & $-\cdot / \cdot \Delta$ & $\cdot / 49$ & $r / \Delta r$ & $11 / \Delta \Lambda$ & r. حمايت دوستان \\
\hline & & & & 1 & $\cdot / Y F$ & $.199^{*}$ & (1/ & $-\cdot / \cdot f$ & $-\cdot / \kappa$. & r/ar & س & F. حمايت ديخران \\
\hline & & & 1 & ·/^ґ* & $\cdot / V 9^{*}$ & $\cdot / \wedge r^{*}$ & $\cdot /$ IF & $\cdot / \cdot f$ & $-\cdot / \cdot f$ & $N / 1 r$ & $\mathrm{rq/9T}$ & ه. حمايت كل \\
\hline & & 1 & $-\cdot / 1 \wedge$ & $\cdot / I V$ & $-\cdot / \cdot r$ & $\cdot / 19$ & $-\cdot / \Delta 1^{*}$ & $-\cdot / f$ & $\cdot / \cdot r$ & $F / Y r$ & $|F / \wedge|$ & 1. افسردگیى \\
\hline & 1 & $\cdot / N r^{*}$ & $-\cdot / r$ & $\cdot / 14$ & $-\cdot / I F$ & $\cdot / r r$ & $-\cdot / \Delta 1^{*}$ & $-\cdot / F r$ & $\cdot / \notin v$ & $F / q$ & $1 f / 9$ & r. اضطراب \\
\hline 1 & $\cdot / V^{*}$ & $\cdot 19^{*}$ & $-\cdot / 19$ &.$/ \cdot 1$ & $-\cdot / \cdot v V$ & $\cdot / 11$ & $-\cdot /$ fr* & $-\cdot / \uparrow \wedge$ & - & $F / \cdot \Delta$ & IV/9T & r. تنيدگى \\
\hline
\end{tabular}

كودك كمت توان ذهنى از روش ركرســيون جنـدمتغيره از نوع خطى استفاده شد. بيش از تحليل اصلى رگرسيون مفروضههاى اين تحليـل از قبيـل هم خطى نبودن جند كانه متغيرها، دادههاى يرت، نرمـال بودن توزيع نمرههـا، و يكســانى واريانس توزيع نمرهها بررسى شـد كه نتايج نشان داد هيج گونه تخطى از اين مغروضسهها وجود ندارد. نتايج حاصـل از تحليل رگرسـيون جندمتغيرى مربوط به بيشبينى بذيرى سلامت روان (افسردگى، اضــطراب، و تنيـدكى) توســط ذهن آكـاهى و ابعاد حمايت اجتماعى در جدول ب خزارش شده است.
همان گونه كه جدول r نشــان مىدهد رابطه ذهن آكاهى با

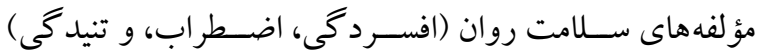
معنى دار و معكوس اسـت ( (P P) بدين معنى كه ميزان بـالاى ذهن آكاهى با افســردگى، اضــطر اب، و تنيد گى يايين همراه اسـتـ. اما در مورد رابطه حمايت اجتماعى و ســلامت روان مادران داراى كودكى كمتوان ذهنى، رابطه معنىدارى به دست نيامد. بـهمنظور آزمون بيش بينى كنتـدكى ذهن آكاهى و حمايت اجتماعى (حمايت خانواده، حمايت دوستان، حمايت ديخران) در سلامت روان (اضطراب، تنيدگى، افسردگى) مادران داراى

جدول بّ: تحليل مربوط به مدل ركرسيون افسردگى، اضطراب، و تنيدكى از روى ذهن آكاهى و حمايت اجتماعى

\begin{tabular}{|c|c|c|c|c|c|c|c|c|}
\hline Fنى معارى F & $\mathbf{F}$ & مجذييرات & $\begin{array}{c}\text { مجذورات } \\
\text { R }\end{array}$ & ميانكين مجذورات & درجه آزادى & مجذوروات & متغير ملاكى & \\
\hline & & & & $\Delta \Delta / N r$ & r & YYY/QI & افسردگى & \\
\hline & & & & $M M / r Y$ & r & $r \Delta r / r v$ & اضطراب & ركرسيون \\
\hline & & & & re/rr & r & $|r q / 9|$ & تنيدگى & \\
\hline$\% / \cdots 9$ & $r / 91$ & $\cdot /$ TVG & $\cdot / T V G$ & $\mid F / Y \Delta$ & \&l & $\Delta \Lambda F / Y Y$ & افسردگى & \\
\hline$\% r$ & F/a9 & . /rY4 & / /rYq & IV/A. & +1 & VYq/VG & اضطراب & باقىمانده \\
\hline \multirow[t]{4}{*}{.$/ 19$} & $\cdot / \cdot v$ & $\cdot / 1 \wedge 9$ &.$/ 1 \wedge 9$ & $1 F / 9 \mathrm{~V}$ & +1 & $9 \cdot . / 1$ & تيدگى & \\
\hline & & & & & ra & $\lambda \cdot V / M r$ & افسردگى & \\
\hline & & & & & Fo & $1 \cdot \wedge r / \cdot r$ & اضطراب & كل \\
\hline & & & & & fo & $V r V / \Lambda I$ & تنيدگى & \\
\hline
\end{tabular}


توانستند/\%/Y از واريانس اضطراب مادران را يِيشبينى كنند، اما هيج كدام از متغيرهاى ذهن آكاهى و ابعاد حمايت اجتماعى النى

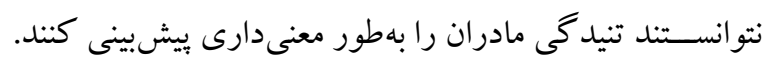

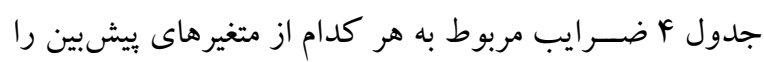
نشان ميدهد.
همـانطور كـه در جـدول ب نشــان داده شـــدهاســت، ذهن آكاهى و ابعاد حمايت اجتماعى تو انستند افسردگى مادران را بيشبينى كنتـد، بـدين معنى كـه ذهن آكتاهى و و حمـايست

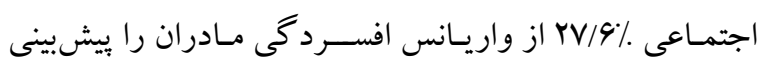

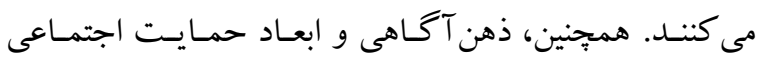

\begin{tabular}{|c|c|c|c|c|c|}
\hline Beta معنى دارى & ضرايب همبستكى جزئى & Beta & B & متغير ملاك & متغير ييش بين \\
\hline$\% \cdot 1$ & $\cdot / 4 \lambda$ & $\cdot / \Delta$ & $\cdot / \pi$ & افسردگى & \multirow{2}{*}{ ذهن آكَاهى } \\
\hline$\% \cdot 1$ &.$/ 49$ &.$/ 49$ & $\cdot /$ IF & اضطراب & \\
\hline$\cdot / A \cdot 4$ & $-\cdot / \cdot r$ &.$- / \cdot \Delta$ & -.1 .9 & افسردگى & \multirow{2}{*}{ حمايت خانو اده } \\
\hline.$/ 1 r 9$ & $\cdot / r$ & $-\cdot / / 9$ & $-\cdot / F F$ & اضطراب & \\
\hline - /VF. & .1 .4 &.$/ \cdot \Delta$ & .19 & افسردگى & \multirow{2}{*}{ حمايت دوستان } \\
\hline .11 .9 & $\cdot / r \mid$ & M & 每 & اضطراب & \\
\hline $.19 \pi \pi$ & -.1 .4 & $-\cdot / \cdot \wedge$ &.$- / \cdot 1$ & افسردگى & \multirow{2}{*}{ حمايت ديخران } \\
\hline$\cdot / \mathrm{V} / 9$ &.$/ \cdot \Delta$ & $.1 \cdot 9$ & $\cdot / \cdot 1$ & اضطراب & \\
\hline
\end{tabular}

موقعيتهاى تنش آور مانند داشتن يكك كود كك كمتوان ذهنى مؤثر باشد.

همسـو با اين بزؤهش سـينگك و همكاران (11) نشان دادند ذهن آكاهى مـادران در بيامدهاى ســلامت روانى كود كان از جمله كاهش برخاشــرى و افزايش رفتارهاى اجتماعى آنان

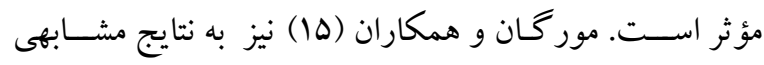
دسـت يافتند، به اين صــورت كه بيماران با ســطوح بيشـتر ذهن آكاهى، افسردگ

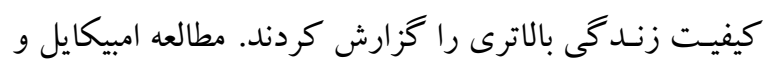

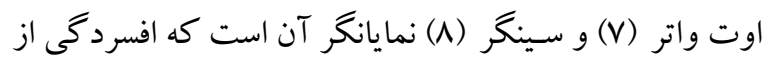

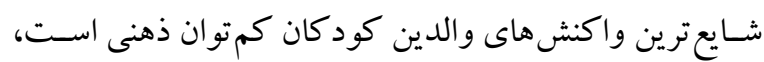

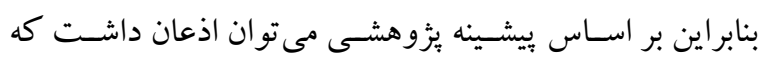

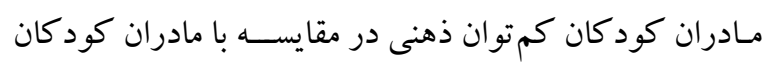
بهنجار از سـلامت روانى بايين ترى برخوردار هستند؛ به عبارت

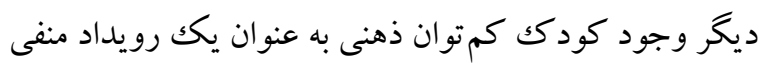

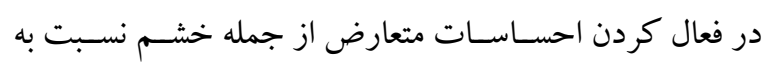

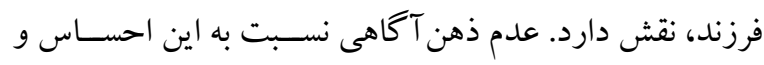

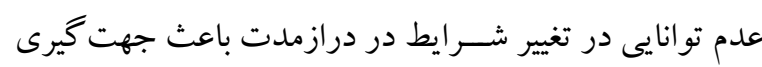

همـانطور كـه جـدول \& نشــان مىدهـد از بين متغيرهاى

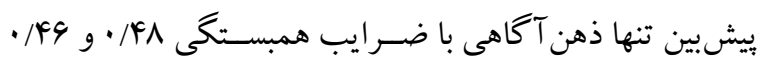

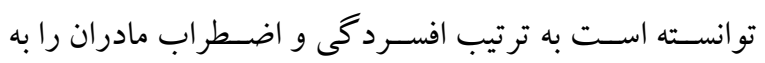

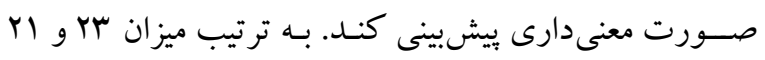

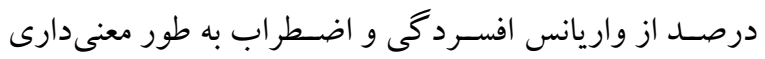

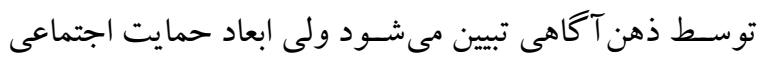

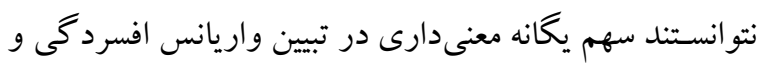

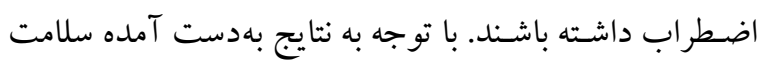

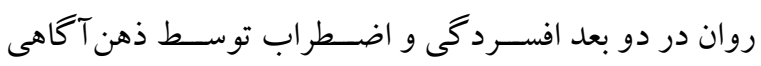
يّيشبينى مىشــود، اما تنيدگى مادران داراى كود كى كم توان ذهنى توسط هيج كدام از اين متغيرها بيشبينى نشد.

\section{بحث و نتيجل كيرى}

يافتهاى اين يزوهش نشان داد بين ذهن آكاهى و سلامت روت روان

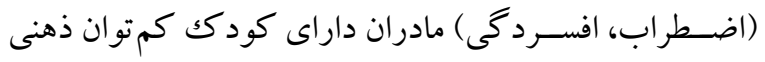
رابطه معنىدارى وجود دارد. اين نتيجه نشـان مىدهد بالا بودن

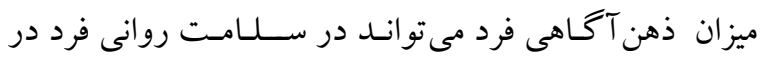


بهزيسـتى تا حدودى كمبود حمايت اجتماعى ادراكك شــده از

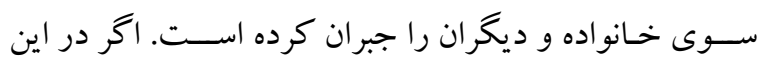

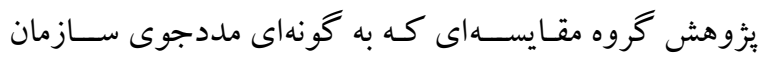

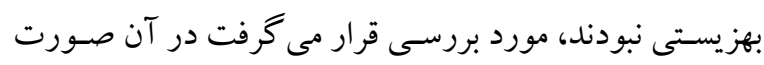
مى توانست تفاوت حمايتهاى اجتماعى دريافت شده از سوى ترى

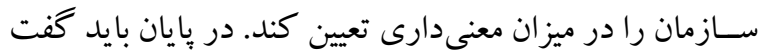

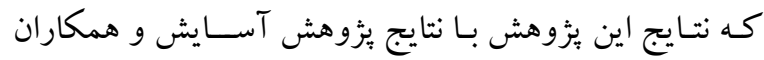

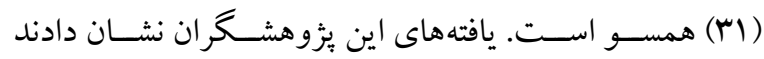

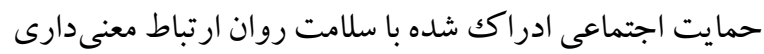

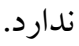

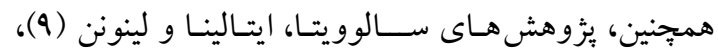

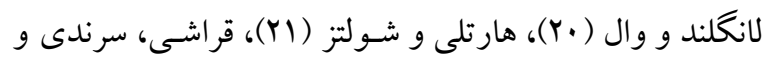

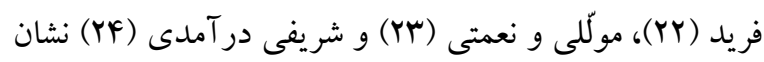
دادند كه بين حمايت اجتماعى ادراككشـــه و ســلامت روان رابطه مثبت و معنىدارى وجود دارد، بدين معنى افرادى كه از حمـايـت بـالـاترى برخوردارنــد در برابر اختلـالات روانى مانند اضطراب و افسردگى، كمتر آسيب يذيرند. مغايرت نتايج اين

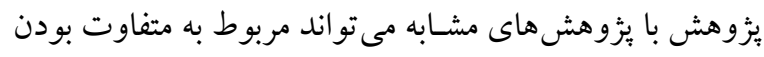

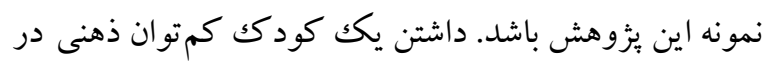

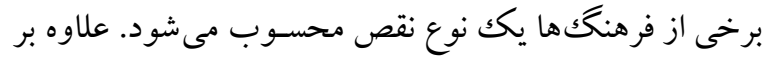

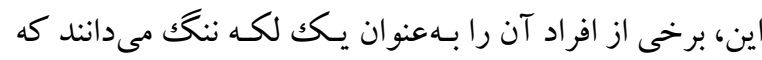

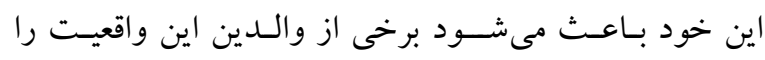

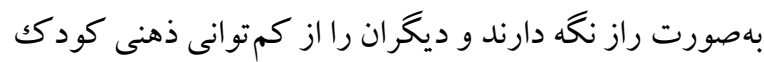
خود مطلع نكنتـد كـه بـهنوبـه خود ســبب عدم جلب حمايت

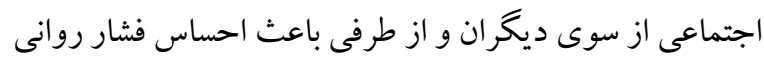
و اضطر اب و افسردگى شود. همجنين اين احتمال وجود دارد

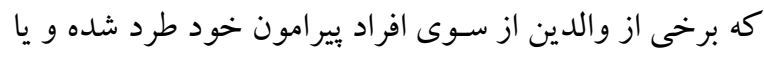
روابط اجتماعى كمترى با افراد فاميل، دوسـتان، و خانو ادههاى

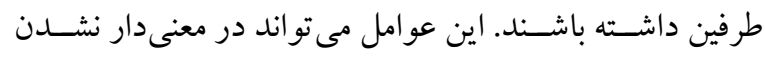

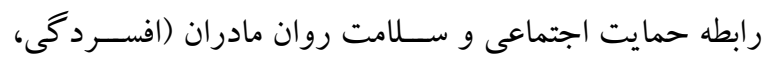
اضطراب، تنيدگى) در اين مطالعه مؤثر بوده باشد.
خشم به سمت خود مادر شده و به دليل كامنايافتكى در مواجه با خشم منجر به افسردگى مىشود (qه). البته لازم به ذكر است

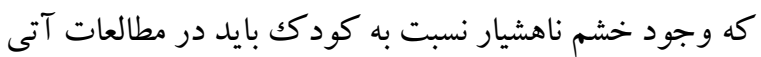
به طور دقيق تر بررسى شود. بنابر اين، نتايج اين يزوهش به طور

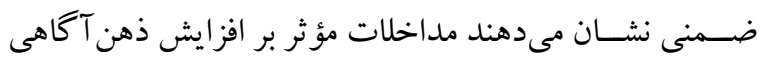
والـدين كودكـان كمتوان ذهنى، ســلامت روان آنان را ارتقاء خو اهد داد. از طرفى آكاهى نسبى به كامنايافتكى هاى ناشى از وجود فرزند كم توان ذهنى در خانو اده مى تواند اضطر اب رادر والدين ايجاد كند. اضطر اب مادر همجنين مى تواند از الزامات مراقبـت از كودكك كمتوان ذهنى، از جملـه هزينـهــا، نحوه

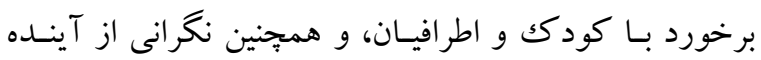
كودكى، ناشى شده باشد. يافتهاى اين يُوهش نشــان داد رابطه معنى دارى بين ابعاد

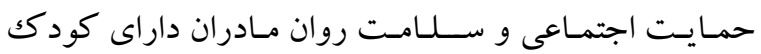
كم توان ذهنى وجود نــارد. اين يـافتهـ با بزووهش هاى مشــابه

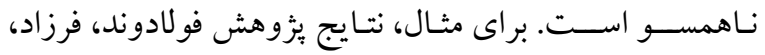

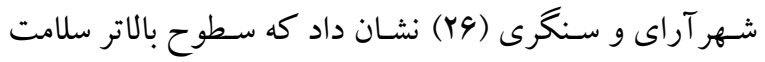

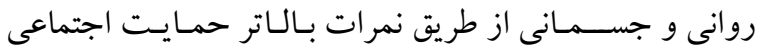
بيشبينى مىشـود. همجينين يافتهاى يُزوهش آزادى و آزاد

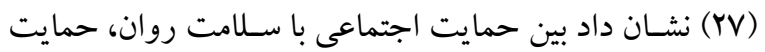

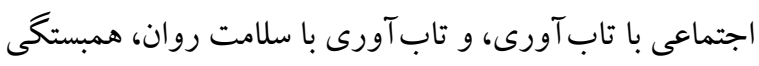
معنىدارى وجود دارد، كه در اين ميان حمايت اجتماعى سـاير

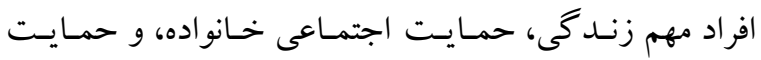
اجتماعى دوسـتان بهترتيب بيشـترين ارتباط را با سـلامت روان دارند. نتايج بزوهش بحرى، دهقان منشـادى و دهقان منشـادى كمان (YN)، نشـان داد كه حمايت اجتماعى با سـلامت روانى والدين كود كان ناشنوا و نابينا رابطه دارد و قادر است تا سلامت روانى

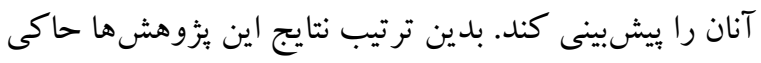

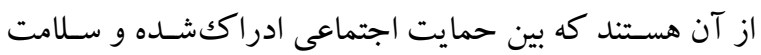
روان رابطهه مثبـت و معنادارى ديده مى شـــود و افراد از لحاظ

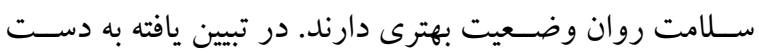
آمـده در اين مطـالعهه مى توان گفـت حمـايـت هـاى ســازمان 
بيشـترى، يافته ها را تعميم داد. همجينين آموزش ذهن آكاهى به عنوان يكى از متغيرهاى مؤثر بر تضـمين سلامت روانى والدين كود كان كم توان ذهنى، يك موضوع بسيار ضرورى است.

تشـكر و قدردانى: اين يزوهش بر گرفته از پيايان نامه كارشـناسـى

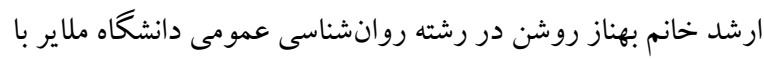

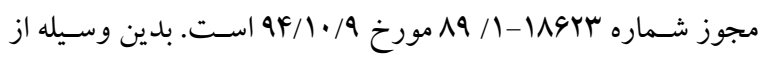
تمامى مسئولين اداره بهزيستى و آموزش و يرورش و همجنين مادران

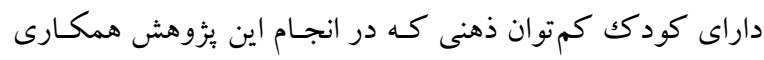

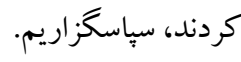

تضــاد منافع: اين بزووهش براى نويسندگان هيج گونه تضاد منافعى نداشته است.
يزٔوهش حاضـر محدوديتهايى را داتشـه اسـت كه در به

دســت آوردن نتـايج آن بى تـأثير نبوده اســت. برخى از اين

محسدوديـتهــا عبـارتانـد از: اســتفـاده از روش نمونه خيرى غير تصـادفى، عدم كنترل متغيرهاى واسـطهاى مؤثر بر سـلامت روان مادران، يايين حجم نمونه، محدود بودن سـن افراد نمونه، و احتمال همبودى كمتوانى ذهنى با ساير اختلال هاى روانى در

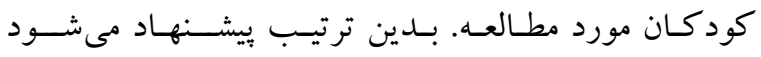
يثزوهش هاى مشـابهى با رفع اين محدوديت ها درباره ســلامت روانشــــاختى هر يكك از اعضـــاى خانو اده كود كان كمت توان ذهنى (مـانند يدر، مادر، برادر و خواهر) صــورت گيرد تا هم دقـت نتـايج بـه دسـت آمــده افزايش يـابد و هم بتوان با توان 


\section{References}

1. Afrooz Q, Taghizadeh H. Comparison of perceived social support and mental health of mothers of children with and without hearing-impairment. Exceptional Education. 2014; 2(124): 7-17. [Persian]. [Link]

2. Malekshahi F, Fallahi S. Parent's mentally retarded child psycho-social problems covered by welfare centers khorramabad 2013. Yafte. 2016; 18(3): 42-51. [Persian]. [Link]

3. Sutinah S, Saswati N. Psychoeducation therapy reduces burden and improves family ability in caring for mental retardation children. Indonesian Nursing Journal Of Education And Clinic (INJEC). 2017; 2(1): 85-104. [Link]

4. Ershad Sarabi R, Hashemi Razini H, Abdollahi MH. Comparing parental stress, parenting styles, and social problem solving in mothers of children with autism spectrum disorder, ADHD, and typically developing children. Quarterly Journal of Child Mental Health. 2018; 4(4): 165-179. [Persian]. [Link]

5. Zamani N, Ansari Shahidi M. Prevalence of psychological disorders among caregivers of children with intellectual disabilities and motor disabilities in Hamadan. Quarterly Journal of Child Mental Health. 2017; 4(3): 119-129. [Persian]. [Link]

6. Aghaei S, Yousefi Z. The effectiveness of quality of life therapy on psychological capitals and its dimensions among mothers of children with intellectual disability. Quarterly Journal of Child Mental Health. 2017; 4(2): 49-59. [Persian]. [Link]

7. Ambikile JS, Outwater A. Challenges of caring for children with mental disorders: Experiences and views of caregivers attending the outpatient clinic at Muhimbili National Hospital, Dar es Salaam Tanzania. Child Adolesc Psychiatry Ment Health. 2012; 6(1): 16. [Link]

8. Singer GHS. Meta-analysis of comparative studies of depression in mothers of children with and without developmental disabilities. Am J Ment Retard. 2006; 111(3): 155-169. [Link]

9. Saloviita T, Itälinna M, Leinonen E. Explaining the parental stress of fathers and mothers caring for a child with intellectual disability: a Double ABCX Model. J Intellect Disabil Res. 2003; 47(Pt 4-5): 300312. [Link]

10. MacDonald EE, Hastings RP. Mindful parenting and care involvement of fathers of children with intellectual disabilities. J Child Fam Stud. 2010; 19(2): 236-240. [Link]

11. Singh NN, Lancioni GE, Winton ASW, Singh J, Curtis WJ, Wahler RG, et al. Mindful parenting decreases aggression and increases social behavior in children with developmental disabilities. Behav Modif. 2007; 31(6): 749-771. [Link]

12. Ki E-J, Jang J. Social support and mental health. Journal of Asian Pacific Communication. 2018; 28(2): 226-250. [Link]

13. Baer RA. Mindfulness training as a clinical intervention: a conceptual and empirical review. Clin Psychol. 2003; 10(2): 125-143. [Link]

14. Schutte NS, Malouff JM. Emotional intelligence mediates the relationship between mindfulness and subjective well-being. Pers Individ Dif. 2011; 50(7): 1116-1119. [Link]

15. Morgan NL, Ransford GL, Morgan LP, Driban JB, Wang C. Mindfulness is associated with psychological symptoms, self-efficacy, and quality of life among patients with symptomatic knee osteoarthritis. Osteoarthritis Cartilage. 2013; 21: S257-258. [Link]

16. Öst L-G. Efficacy of the third wave of behavioral therapies: A systematic review and meta-analysis. Behav Res Ther. 2008; 46(3): 296-321. [Link]

17. Olafsen $\mathrm{AH}$. The implications of need-satisfying work climates on state mindfulness in a longitudinal analysis of work outcomes. Motiv Emot. 2017; 41(1): 22-37. [Link]

18. Brown KW, Ryan RM. The benefits of being present: mindfulness and its role in psychological wellbeing. J Pers Soc Psychol. 2003; 84(4): 822-848. [Link]

19. Ghasemipour Y, Ghorbani N. Mindfulness and basic psychological needs among patients with coronary heart disease. Iranian Journal of Psychiatry and Clinical Psychology. 2010; 16(2): 154-162. [Persian]. [Link] 
20. Langeland E, Wahl AK. The impact of social support on mental health service users' sense of coherence: A longitudinal panel survey. Int J Nurs Stud. 2009; 46(6): 830-837. [Link]

21. Hartley SL, Schultz HM. Support needs of fathers and mothers of children and adolescents with autism spectrum disorder. J Autism Dev Disord. 2015; 45(6): 1636-1648. [Link]

22. Gharashi K, Sarandi P, Farid A. The comparison of stress and marital satisfaction status of parents of hearing-impaired and normal children. Bimonthly Audiology - Tehran University of Medical Sciences. 2013; 22(1): 18-24. [Persian]. [Link]

23. Movallali G, Nemati S. Difficulties in parenting hearing-impaired children. Bimonthly Audiology Tehran University of Medical Sciences. 2009; 18(1): 1-11. [Persian]. [Link]

24. Sharifi Daramadi P. The effect of emotional intelligence training on mental health of mothers with educable mental retarded children. Journal of Family Research. 2009; 4(4): 423-439. [Persian]. [Link]

25. Alonso-Sardón M, Iglesias-de-Sena H, Fernández-Martín LC, Mirón-Canelo JA. Do health and social support and personal autonomy have an influence on the health-related quality of life of individuals with intellectual disability? BMC Health Serv Res. 2019; 19: 63. [Link]

26. Fooladvand K, Farzad VA, Shahraray M, Sangari AA. Role of social support, academic stress and academic self-efficacy on mental and physical health. Contemporary Psychology, Biannual Journal of the Iranian Psychological Association. 2010; 4(2): 81-93. [Persian]. [Link]

27. Azadi S, Azad H. The correlation of social support, tolerance and mental health in children of martyrs and war-disabled in universities of Ilam. Iranian Journal of War and Public Health. 2011; 3(4): 48-58. [Persian]. [Link]

28. Bahri SL, Dehghan Manshadi M, Dehghan Manshadi Z. To investigate the effect of predicting resiliency and social support in general mental health in parents of deaf and blind children. Exceptional Education. 2014; 1(123): 5-12. [Persian]. [Link]

29. Park N, Heo W, Ruiz-Menjivar J, Grable JE. Financial hardship, social support, and perceived stress. Journal of Financial Counseling and Planning. 2017; 28(2): 322-332. [Link]

30. Gülaçtı F. The effect of perceived social support on subjective well-being. Procedia Soc Behav Sci. 2010; 2(2): 3844-3849. [Link]

31. Asayesh H, Hesam M, Ghorbani M, Shariati A, Nasiri H. The relationship of perceived social support, mental health and life satisfaction in martyrs and veterans students of state university in Gorgan. Journal of Research Development in Nursing \& Midwifery. 2011; 8(1): 34-41. [Persian]. [Link]

32. Zimet GD, Dahlem NW, Zimet SG, Farley GK. The Multidimensional Scale of Perceived Social Support. J Pers Assess. 1988; 52(1): 30-41. [Link]

33. Lovibond SH, Lovibond PF, Australia PF of. Manual for the depression anxiety stress scales. Sydney, N.S.W. : Psychology Foundation of Australia; 1995. [Link]

34. Carlson LE, Brown KW. Validation of the mindful attention awareness scale in a cancer population. $\mathrm{J}$ Psychosom Res. 2005; 58(1): 29-33. [Link]

35. Moradi M, Dehghanizadeh MH, Soleimanikheshab AA. Percieved social support and Academic buoyancy: medaitive role of academic self-efficacy beliefs. Journal of education and learning studies. 2015; 7(1): 1-24. [Persian]. [Link]

36. Sahebi A, Asghari MJ, Salari RS. Validation of depression anxiety and stress scale (DASS-21) for an Iranian POPULATION. Journal of Developmental Psychology. 2005; 1(4): 36-54. [Persian]. [Link]

37. Moradipanah F, Mohammadi E, Mohammadil AZ. Effect of music on anxiety, stress, and depression levels in patients undergoing coronary angiography. East Mediterr Health J. 2009; 15(3): 639-647. [Link]

38. Crawford JR, Henry JD. The depression anxiety stress scales (DASS): normative data and latent structure in a large non-clinical sample. Br J Clin Psychol. 2003; 42(Pt 2): 111-131. [Link]

39. Trunnell TL. The management of the mechanisms of depression in intensive short-term dynamic psychotherapy. International Journal of Short-Term Psychotherapy. 1987; 2: 1-5. [Link] 